\title{
IMPLEMENTASI GOOD GOVERNANCE DI KECAMATAN SABANGAU KOTA PALANGKA RAYA
}

\author{
Implementation of good governance in Sabangau subdistrict, Palangka Raya City
}

\section{Muhamad Yusuf*}

Universitas Muhammadiyah

Palangkaraya, Palangka Raya, Central

Kalimantan, Indonesia

email:

yusuf.quratayun@gmail.com

\section{Kata Kunci: \\ Implementasi \\ Tata Kelola}

Pemerintahan

\section{Keywords:}

Implementation

Good Governance

\section{Accepted}

June 2015

\section{Published}

Oktober 2015

\begin{abstract}
Abstrak
Dalam penulis menggunakan pendekatan kualitatif. Menurut Sugiyono (2011:8) "Metode penelitian kualitatif adalah metode yang digunakan untuk meneliti pada kondisi obyek alamiah". Dimanapeneliti adalah sebagai instrumen kunci, teknik pengumpulan data dilakukan secara triangulasi (gabungan), analisis data yang bersifat induktif, dan hasil penelitian kualitatif lebih menekankan makna dari pada generalisasi. Berdasarkan teori tersebut, peneliti berasalan menggunakan metode penelitian kualitatif karena ingin memahami faktor sosiologis, situasi, dan gejala atau fenomena sosial secara mendalam,dan komperehensif. Dengan pendekatan kualitatif maka peneliti melakukan penelitian pada latar alamiah, maksudnya peneliti melihat kenyataan yang ada dilapangan. Dalam hal ini, peneliti mengamati Tata Kelola Pemerintahan di Kecamatan Sabangau dalam administrasi pemerintahan.
\end{abstract}

\section{PENDAHULUAN}

Pada dekade akhir dalam abad 20 dan dekade awal abad 2 I, bangsa kita sebagaimana bangsa-bangsa lain di berbagai belahan dunia, menghadapi gelombang besar berupa meningkatnya tuntutan demokratisasi, desentralisasi, dan globalisasi. Sekalipun keadaan serupa pernah terjadi pada beberapa kurun waktu dalam sejarah manusia, namun dewasa ini tuntutan tersebut mengemuka dengan nuansa yang berbeda sesua dengan kemajuan zaman,

Globaliasasi yang menyentuh berbagai bidang kehidupan di seluruh wilayah pemerintahan Negara menuntut reformasi sistem perekonomian dan pemerintahan termasuk birokrasinya, sehingga memungkinkan interaksi perekonomian antar daerah dan antar bangsa berlangsung lebih efisien. Kunci keberhasilan pembangunan perekonomian adalah daya saing; dan kunci dari saing adalah efisiensi proses pelayanan, serta mutu keteatan dan kepastian kebijakan publik.

Dewasa ini Indonesia saat ini menghadapi berbagai tantangan dalam penerapan tata kelola pemerintahan yang membutuhkan perhatian serius dari semua pihak. Good Governance atau tata pemerintahan merupakan bagian dari paradigm baru yang berkembang dan memberikan nuansa yang cukup mewarnai krisis multi dimensi seiring dengan tuntutan era reformasi. Situasi ini menuntut adanya kepemimpinan nasional masa depan, yang diharapkan mampu menjawab tantangan bangsa Indonesia mendatang. 
Keberhasilan dan kegagalan sebuah organisasi sangat ditentukan dari cara dan gaya kepemimpinan seseorang dalam memimpin dan menjalankan roda organisasi. Dalam pelaksanaan pembangunan pemerintah wajib memberikan bimbingan, pengarahan, bantuan, dan fasilitas yang diperlukan. Sedangkan masyarakat memberikan partisipasi aktif dalam bentuk swadaya gotong royong masyarakat pada setiap kegiatan pembangunan yang dilaksanakan.

Reformasi dilakukan untuk mewujudkan apartur negara yang mampu mendukung kelancaran dan keterpaduan pelaksanaan tugas dan fungsi penyelenggaraan pemerintahan negara dan pembangunan, dengan mempraktekkan prinsip-prinsip Good Governance. Selain itu, masyarakat menuntut agar pemerintah memberikan perhatian yang sungguh-sungguh dalam memberantas praktek-praktek korupsi, kolusi, dan nepotisme, sehingga tercipta pemerintahan yang bersih dan mampu menyediakan pelayanan yang prima sebagaimana diharapkan masyarakat. Agar harapan tersebut dapat menjadi kenyataan, maka dituntut adanya suatu sikap apartur yang baik, integritas, profesionalisme serta etos kerja dan moral yang tinggi.

Pelaksanaan Otonomi Daerah yang telah digulirkan oleh pemerintah sejak tahun 1999 membawa perubahan dalam pelaksanaan pemerintahan di daerah. Salah satu perubahan itu adalah pemberian wewenang yang lebih luas dalam penyelenggaraan beberapa bidang pemerintahan. Seiring dengan bertambah luasnya kewenangan ini, maka aparat pemerintahan di daerah diharapkan dapat mengelola dan menyelenggarakan pelayanan dengan lebih baik dari sebelumnya sesuai dengan kebutuhan dan harapan masyarakat.

Dalam pelaksanaan Good Governance pemerintah seringkali mendapat berbagai kendala. Salah satu kendala dalam pelaksanaannya adalah kurang adanya komunikasi yang baik anatara pemerintah dengan masyarakat, dimana masyarakat sebagai pengguna layanan harus mengetahui program-program pemerintah dan informasi-informasi tentang pelayanan. Sehingga keterlibatan setiap warga negara menjadi syarat mutlak bagi tercapainya tujuan nasional dalam menerapkan sistem pemerintahan yang baik. Namun dibalik itu semua telah muncul suatu pemikiran yang positif yaitu munculnya ide serta tentang pemikiran dasar yang menimbulkan reformasi total dalam kehidupan berbangsa dan bernegara. Tujuan utama dari reformasi adalah untuk menciptakan masyarakat sipil (civil society) dalam kehidupan pemerintahan, bermasyarakat, dan bernegara yang memiliki nilai-nilai good governance serta menjunjung tinggi nilai-nilai demokrasi, sikapketerbukaan, kejujuran dan keadilan yang berorientasi kepada rakyat dan bertanggung jawab kepada rakyat.

Kecamatan sabangau sebagai pelaksana dan perencana program pembangunan, di wilayahnya harus dapat berperan sebagai pelayan masyarakat dalam urusanurusan administrasi dan kependudukan yang menjadi wewenangnya, tetapi hal ini dapat dilaksanakan jika pemerintah Kecamatan Sabangau bekerja sama dengan masyarakat sehingga apa yang menjadi tujuan dapat tercapai, namun hingga saat ini berdasarkan pengamatan penelitidan beberapa informasi dari masyarakat terkait pelayanan yang diberikan pihak Kecamatan Sabangau Kota Palangka Raya masih belum optimal dan prosedur yang ditetapkan berbelit-belit dan sering menyulitkan masyarakat dalam mengurus surat ijin tertentu di Kecamatan.

\section{METODOLOGI}

Dalam penelitian ini penulis menggunakan pendekatan kualitatif. Menurut Sugiyono (2011:8) "Metode penelitian kualitatif adalah metode yang digunakan untuk meneliti pada kondisi obyek alamiah”. Dimana peneliti adalah sebagai instrument kunci, teknik pengumpulan data dilakukan secara triangulasi (gabungan), analisis data yang bersifat induktif, dan hasil penelitian kualitatiff lebih menekankan makna daripada generalisasi. 
Berdasarkan teori tersebut, peneliti beralasan menggunakan metode penelitian kualitatif karena ingin memahami faktor sosiologis, situasi, dan gejala atau fenomena sosial secara mandalam, dan komperhensif. Dengan pendekatan kualitatif maka penelitit melakukan penelitian pada latar alamiah, maksudnya peneliti melihat kenyataan yang ada dilapangan. Dalam hal ini peneliti mengamati Tata Kelola Pemerintahan di Kecamatan Sabangau dalam administrasi Pemerintahan.

\section{HASIL DAN PEMBAHASAN}

Dari hasil penelitian mengenai Impelementasi Good Governance di Kecamatan Sabangau Kota Palangka Raya, ditemukan berbagai macam permasalahan atau habatan yang peneliti temukan dari hasil penelitian yang focus pembahasannya adalah Implementasi good governance oleh peneliti secara langsung berdasarkan Tupoksi, dan Tata Kerja kecamatan Sabangau Kota Palangka Raya.

$\mathrm{Hal}$ ini diperkuat dengan pembuktian berdasarkan hasil wawancara dan pengamataan kepada beberapa narasumber yang dianggap dapat dipercaya serta relevan, yaitu dari pihak pegawai Kecamatan dan Masyarakat Kecamatan Sabangau Kota Palangka Raya, peneliti menemuan hasil penelitian sebagai berikut:

I. Komunikasi

Terkait dengan program-program Kecamatan, pihak Kecamatan sudah menyampaikannya kepada masyarakat Sabangau.

Dari wawancara kepada salah satu Penduduk Sabangau dapat disimpulkan bahwa semua program-program Kecamatan Sabangau sudah di sampaikan kepada masyarakat Kecamatan Sabangau tetapi masih belum berjalan sesuai dengan yang diharapkan oleh pihak Kecamatan dikarenakan masih banyak masyarakat yang tidak terlalu aktif dalam mengikuti program-program tersebut.

Selain itu, juga ditemukan pernyataan lain yang serupa tapi tak sama, bahwa masyarakat masih banyak yang belum tahu tentang program-program Kecamatan Sabangau.

Dari pernyataan-pernyataan masyarakat tersebut dapat disimpulkan bahwa sebagian programprogram Kecamatan sudah disampaikan kepada masyarakat tetapi masih belum berjalan dengan maksimal dikarenakan masih banyak masyarakat yang tidak terlalu aktif untuk mengikuti programprogram kecamatan.

\section{Sumber Daya}

Terkait hal ini pegawai Kecamatan Sabangau sudah memberikan pelayanan kepada masyarakat dengan menggunakan sumber daya maupun sarana prasarana yang ada di Kecamatan Sabangau.

Dari hasil wawancara kepada masyarakat sebangau dapat disimpulkan bahwa pegawai Kecamatan Sabangau sudah melaksanakan tugasnya dalam memberikan pelayanan kepada masyarakat Kecamatan Sabangau dengan menggunakan sumber daya manusia maupun sarana prasarana yang ada di Kecamatan Sabangau.

Selain itu, dari hasil wawancara juga dapat disimpulkan bahwa masih banyak masyarakat yang tidak puas dengan pelayanan yang diberikan oleh pegawai Kecamatan dan fasilitas yang ada di Kecamatan Sabangau masih kurang memadai sehingga pelayanan menjadi terhambat.

\section{Disposisi}

Berdasarkann pengamatan dan hasil penelitian di lapangan pegawai Kecamatan Sabangau sudah 
bersikap sopan kepada setiap masyarakat yang sedang berurusan di Kantor Kecamatan, tetapi dalam memberikan pelayanannya pegawai Kecamatan Sabangau masih belum maksimal, karena pegawai Kecamataan Sabangau masih sering tidak ada di tempat ketika jadwal kerja dan masyarakat yang mau berurusan di Kantor Kecamatan Sabangau mejadi terhambat dan tidak terlayani secara maksimal.

\section{Struktur Birokrasi}

Berdasarkan Struktur Birokrasi yang ada di Kecamatan Sabangau maka dapat dikatakan Aturanaturan yang diterapkan oleh pihak Kecamatan masih belum terlaksana dengan maksimal, karena pegawai Kecamatan Sabangau belum menjalankan Tupoksinya dengan baik maupun sesuai dengan aturan-aturan yang berlaku di Kecamatan Sabangau, seperti pelayanan yang diberikan kepada masyarakat. Pegawai Kecamatan Sabangau masih belum cepat dan tepat dalam melayani masyarakat yang sedang berurusan di Kantor Kecamatan Sabangau.

\section{KESIMPULAN}

Berdasarkan hasil penelitian dan pembahasan, maka dapat disimpulkan bahwa Implementasi Good Governance di Kecamatan Sabangau Kota Palangka Raya belum terlaksana dengan baik disebabkan karena:

I. Program-program Kecamatan Sabangau masih belum berjalan dengan maksimal karena sebagian masyarakat tidak terlalu aktif untuk berperan dalam menjalankan program-program Kecamatan. Hal ini dikarenakan pihak Kecamatan masih belum mensosialisasikan secara luas semua programprogram Kecamatan.

2. Suber daya manusia maupun sarana prasaran yang ada di kantor Kecamatan Sabangau masih belum memadai, seperti tempat duduk tamu yang kurang, sebagian computer yang tidak berfungsi, hal ini yang dapat menghambat pelayanan yang ada di Kecamatan Sabangau

3. Pegawai Kecamatan Sabangau dalam melayani masyarakat sudah cukup sopan namun dalam pelayanannya masih belum terlaksana dengan maksimal karena pegawai Kecamatansering tidak ada di tempat. Hal ini yang dapat menghambat pelayanan yang ada di Kecamatan Sabangau

4. Pegawai Kecamatan Sabangau belum melaksanakanan tugasnya dalam melayani masyarakat dengan baik, sesuai aturan-aturan yang berlaku di Kecamatan Sabangau maupun Tupoksinya masing-masing.

Dari kesimpulan berikut, disertakan juga saran-saran:

I. Diharapkan kepada pemerintah kecamatan agar dapat mengkomunikasikan dengan baik kepada masyarakat tentang program-program yang ada di kecamatan Sabangau

2. Diharapkan kepada Pemerintah Kecamatan agar bisa menambah fasilitas umum seperti komputer, mesin fotocopy, printer, dan lain lain yang berhubungan dengan pelayanan agar tercapainya pelayanan yang efektif dan efisien seperti yang diharapkan oleh masyarakat.

3. Diharapkan kepada pegawai Kecamatan Sebangau agar bisa hadir dengan tepat waktu sesuai dengan jam kerja yang sudah ditentukan, agar masyarakat mendapatkan pelayanan yang maksimal

4. Diharapkan kepada Pegawai Kecamatan agar bisa lebih mentaati peraturan dan kebijakan yang telah di tetapkan oleh Pemerintah Kecamatan Sabangau.

\section{REFERENSI}

Achmadi, A. 2015. Kewajiban Pelayanan Publik Oleh Pemerintah Daerah di Era Otonomi. Anterior Jurnal. I4(2):22 I-227.

Anggara, Sahya. 2012. Ilmu Administrasi Negara. Bandung : CV.Pustaka Setia. 
Agustino, Leo. 2014. Dasar-Dasar Kebijakan Publik. Bandung: CV.Alfabeta

Bungin, burhan. 2010. Analisis Data Penelitian Kualitatif, Pemahaman Filosofis dan Metodologis Ke Arah Penguasaan Modal Aplikasi. Jakarta: PT Raja Grafindo Persada

Mulyadi Dedy. 2015. Studi Kebijakan Publik dan Pelayanan Publik. Bandung: Alfabeta.

Pasolong, harbani. 2013. Teori Administrasi Publik. Bandung: CV.Alfabeta

Sedarmayanti. 2004. Membangun Sistem Manajemen Kinerja Guna Meningkatkan Produktivitas Menuju Good Governance (kepemerintahan yang baik). Bandung: Mandar Maju

Tangkilisan, Hessel Logi S. 2007. Kebijakan dan Manajemen Otonomi Daerah. Yogyakarta: Lukman Offset.

Tahir Arifin. 2014. Kebijakan Publik \& Transparansi Penyelenggaraan Pemerintah Daerah. Bandung : Alfabeta.

Wahab, Solichin Abdul. 2014. Analisis Kebijaksanaan Dari Formulasi ke Penyusunan Model-Model Implementasi Kebijakan Publik. Malang : Bumi Aksara.

Widodo, Joko. 20I3. Analisis Kebijakan Publik. Malang : Media Nusa Creative

Winarno, Budi. 20I4. Kebijakan Publik (Teori, Proses dan Studi Kasus). Caps. Yogyakarta.

Yusuf, Muhammad, 2013. Implementasi Kebijakan Pelayanan Pendidikan Dasar Di Daerah Terpencil Kabupaten Pulang Pisau Provinsi Kalimantan Tengah. Disertasi Pada Pascasarjana Universitas Padjajaran. Tidak Diterbitkan. 